19 Benjet C, Bromet E, Karam EG, Kessler RC, McLaughlin KA, Ruscio AM, et al. The epidemiology of traumatic event exposure worldwide: results from the World Mental Health Survey Consortium. Psychol Med 2016; 46: 327-43.

20 Freedman R. Investigating trauma as a risk factor for psychosis. Schizophr Bull 2017; 43: 1-2

21 Liu H, Petukhova MV, Sampson NA, Aguilar-Gaxiola S, Alonso J, Andrade LH, et al. Association of DSM-IV posttraumatic stress disorder with traumatic experience type and history in the World Health Organization World Mental Health Surveys. JAMA Psychiatry 2017; 74: 270-81.

22 McLaughlin KA, Kubzansky LD, Dunn EC, Waldinger R, Vaillant G, Koenen KC. Childhood social environment, emotional reactivity to stress, and mood and anxiety disorders across the life course. Depress Anxiety 2010; 27: 1087-94.
23 McCrory EJ, De Brito SA, Sebastian CL, Mechelli A, Bird G, Kelly PA, et al. Heightened neural reactivity to threat in child victims of family violence. Curr Biol 2011; 21: R947-8.

24 DePrince AP, Weinzierl KM, Combs MD. Executive function performance and trauma exposure in a community sample of children. Child Abuse Negl 2009; 33: $353-61$

25 Kapur S. Psychosis as a state of aberrant salience: a framework linking biology, phenomenology, and pharmacology in schizophrenia. Am J Psychiatry 2003; 160: 13-23.

26 Barker V, Gumley A, Schwannauer M, Lawrie SM. An integrated biopsychosocial model of childhood maltreatment and psychosis. $\mathrm{Br}$ Psychiatry 2015; 206: 177-80.

\title{
Kathleen Jones' Asylums and After. A Revised History of the Mental Health Services: From the Early 18th Century to the 1990s (1993)
}

\section{George Ikkos}

Kathleen Jones, daughter of a lorry driver, was brought up on a council estate and won scholarships to North London Collegiate School and Westfield College, where she studied history. During WWII Westfield was relocated to Oxford, where Jones edited the oxford Socialist. She married a priest and became interested in mental health when he was appointed chaplain to a mental hospital in the 1940s. This was almost 100 years after the Lunacy Act 1845, which compelled counties to create mental asylums. By the time Asylums and After was published, Jones was a former Chair of the Association of Psychiatric Social Workers, Hon. FRCPsych and Emerita Professor and former Head of Department of Social Policy at York University.

Having been a devout member of the Church of England, Jones' attention to the facilitative role of religion in the development of the asylum system is unusual and a reason to read the book. She acknowledges great faith-based social reformers, such as the 'Clapham Set' around William Wilberforce, who developed social action policies for the Evangelical Movement, and the 7th Earl of Shaftesbury, who for almost 60 years dedicated his parliamentary career to mental health law and asylum development. The book's strongest aspect is detailed attention to parliamentary politics and the tension between central and regional authorities, as they impinge on the plight of mentally ill people.

County asylums literally transformed the landscape during the 19th century. Rising to dominate the skyline at the edge of towns and often being the largest local employer, their numbers rose from 9 in 1828 to 98 in 1930, and the number of inmates from a mere 1046 to an astonishing 119659. Even allowing for the great increase in general population during those years, a 'great confinement' (Foucault) had taken place. Jones argues that psychiatrists of the era advocated small asylums capable of generating a homely atmosphere, much like the York Retreat, but local authorities, in their search of economies of scale, drove their excessive expansion. Her moderate stance towards psychiatrists was exceptional for social scientists writing at the time. I first read Asylums and After in the second half of the 1990s, as a young consultant anxious about de-institutionalisation, and it was comforting for me at the time, though I retained some suspicion about its overall thesis.

Appearing after the Community Care Act 1990 that signalled the effective supremacy of ideologies of 'de-institutionalisation', 'normalisation' and 'advocacy' in the UK, Asylums and After was a committed defence of mental hospitals and a call for quality services for mentally ill people wherever they may be. It emerged in an intellectual landscape that was illuminated (or shadowed, depending on one's point of view) by the ideas of the 'anti-psychiatry' movement. Jones' overwhelmingly negative appraisal of the anti-psychiatrists and what she called their 'ideologies of destruction' diminishes rather than adds to the value of her book. With this caveat, one of its strengths is its focus on the influence of libertarianism on mental health from the 1960s onwards. Jones' horror is palpable when describing the Tory Minister of Health Enoch Powell, the leading libertarian politician of the time, and his famous 'water towers' speech given before an unsuspecting audience at the Annual Conference of the Association for Mental Health in 1961. Significantly, this was also the year Goffman, Foucault and Szasz published their seminal 'anti-psychiatry' works.

Experience has shown that Jones and others were right to worry about de-institutionalisation in the UK and beyond. Nevertheless, change was both morally and health-economically necessary and has made a positive difference for many. Reading Asylums and After again, I find it somewhat paternalistic and insensitive to more subtle aspects of patients' vulnerability in the face of medical authority and institutional powers. With respect to the former it pales by comparison with Roy Porter's more reflective Madness and with respect to the latter by comparison with Michel Foucault's controversial but ground-breaking History of Madness. Together, the three offer a most lively and balanced introduction to the social history of psychiatry. 